\title{
Knowledge and Opinions of Assiut University Students toward Organ Donation and Transplantation
}

\author{
Mervet Salem Abd El Rhman, Safaa Ahmed Kotb, Wafaa Shaaban Sayed \& Soad Abd El Hamed Sharkawy. \\ Nursing specialist, El Ganaiem Central hospital. \\ Assistant professor of Community Health Nursing, Faculty of Nursing. Assuit University. \\ Lecturer of Public Health Medicine, Faculty of Medicine. Assuit University.
}

\begin{abstract}
Organ transplant in Egypt presents difficult ethical and legal challenges for both the transplant community and society. Aim of the study: Evaluate the level of knowledge toward organ donation and transplantation among Assiut University students and assess their opinions about organ donation. Subjects and Method: Descriptive research design was used in this study. The study included (1075) students, were selected randomly from six facilities at Assiut University. through a period extended from February (2013) to the end of April (2013). Data of this study was collected by using self-administered questionnaire. Results: The mean age of students \pm SD was $(20.02 \pm 1.45)$. Less than two thirds of them were females and live in a rural area. (53.8\%) of students from non health faculties. There was a statistically significant difference between students' age, sex, faculty type and grades at college, with their knowledge about organ donation and transplantation. Conclusion: less than two thirds of students had poor knowledge about organ donation and transplantation, and the majority of them had negative opinions about it. Recommendations: Improve students' awareness by conducting ongoing scientific seminars for students and provide brochures on this subject in the university library.
\end{abstract}

Keywords: Organ Transplantation, Organ Donation, Knowledge, Opinions \& Students.

\section{Introduction}

During the past 50 years, the transplantation of human organs, tissues, and cells has become a worldwide practice that has extended and greatly enhanced the quality of hundreds of thousands of lives. Continuous improvements in medical technology, particularly with respect to organ and tissue rejection, have led to increased demand for organs and tissues (WHO, 2011).

Organ transplantation is the moving of an organ from one body to another or from a donor site to another location on the patient's own body, for the purpose of replacing the recipient's damaged or absent organ. Organs and/or tissues that are transplanted within the same person's body are called autografts. Transplants that are recently performed between two subjects of the same species are called allograft, It can be either from a living or cadaveric source. Organs that can be transplanted are the heart, kidneys, liver, lungs, pancreas, intestine, and thymus. Tissues include bones, tendons (both referred to as musculoskeletal grafts), cornea, skin, heart valves, nerves and veins (Khan et al., 2011).

Organ donors may be living, brain dead, or dead via circulatory death. Tissue may be recovered from donors who die of circulatory death, as well as of brain death - up to 24 hours past the cessation of heartbeat. Unlike organs, most tissues (with the exception of corneas) can be preserved and stored for up to five years, meaning they can be "banked" (WHO, 2008).

Worldwide, approximately (100,900) solid organ transplants are performed each year: $(69,300)$ kidney transplants, $(20,300)$ liver transplants $(15 \%$ from living donors), $(5,330)$ heart transplants, $(3,330)$ lung transplants, $(2,380)$ pancreas transplants and (260) small bowel transplants (WHO, 2010).

In Egypt, more contested than any other bioethics topic, organ transplantation has been taken up in the mass media - in print, state television, radio, film, and religious sermons. Patients, family members, physicians, and others in Egypt differ in opinions about whether it is permissible to take a body part from the dead, whether it is a safe or beneficial practice to cut into a healthy living donor, whether organ transplantation actually "saves lives", and about the vulnerability of poor Egyptian bodies to a black market in organs and to organ theft (Hamdy, 2010).

Egypt commenced living donor kidney transplantation in 1980; living-donor liver transplantation was first attempted in Egypt in 1991 by the surgical team at the National Liver Institute, Menoufiya University. At that time, only three livingdonor liver transplantation procedures were performed, with the help of an overseas surgical 
team, and the longest recipient survival was 11 months (El-Elemy and El-Gazzaz, 2010).

The act of donation is in itself an individual decision that requires a depth of understanding that interacts with the social setting and the institutional and regulatory framework into which an individual is embedded (Saleem et al., 2009). Public attitudes and awareness of organ donation and transplantation are key elements affecting donation rates (Rodrigue et al., 2009).

Nurses play vital role in the transplant process through education, advocacy and support, ultimately improving compliance and enhancing quality and longevity of life for transplant recipients. Nurses have an obligation to educate patients, the patients' family and the public (Cebeci et al., 2011). Nursing personnel are fundamental in the organ donation and transplantation process, and their attitude toward donation has a decisive effect on patients, nurses are becoming more and more important in the care and promotion of health care matters in the general public; nurses' attitude affects public opinion, given their position as health care professionals (Zambudio et al., 2009).

\section{Significance of the study}

An extremely high burden of end-stage liver disease and hepatocellular carcinoma is found in the Egyptian population. It is estimated that 42,000 individuals are currently in need of a kidney or liver transplant [vs. 1280 transplants performed in 2008; however, it is estimated that the number in need of transplants will exceed 100,000 by 2020 years based on the current population burden of Hepatitis $\mathrm{C}$ virus (HCV) infection (WHO 2011). Estimates suggest that Egypt performs approximately 500-1000 transplants per year and that between $80 \%$ and $90 \%$ of living kidney donors in Egypt are unrelated /commercial donors (Budian and Mostafa, 2010).

Patients, family members, physicians, and others in Egypt differ in opinions about whether it is permissible to take a body part from the dead, whether it is a safe or beneficial practice to cut into a healthy living donor, whether organ transplantation actually "saves lives", and about the vulnerability of poor Egyptian bodies to a black market in organs and to organ theft (Hamdy, 2010).

\section{Aim of the study}

1. To evaluate the level of knowledge toward organ donation and transplantation among Assiut University students.

2. To assess Assiut University students' opinions about organ donation.

\section{Research questions}

1. What is the level of students' knowledge about organ donation and transplantation?

2. What are the students' opinions about organ donation?

3. Is there a relationship between the personal characteristics of students and their knowledge, opinions regarding organ donation and transplantation?

\section{Subject and methods}

Research design: Descriptive cross sectional research design was used in this study.

Setting

This study was conducted at six faculties in Assiut University (Faculty of Medicine, Nursing, Pharmacy, Physical Education, Law and Arts) during academic year 2012-2013.

\section{Sample}

The total number of faculties in Assuit university was (15) faculty, we selected $40 \%$ from these faculties divided to 3 health science faculties called (Medicine, Nursing and Pharmacy) and 3 non health science faculties called (Arts, law, and Physical Education), which selected randomly. The total number of Assuit university students during academic year 2012-2013 was approximately 60000 students, and we take $2 \%$ from this number. So The total sample size was 1075 students. Sample size has been taken equally from each group ( 537) students whose selected randomly. Proportional sample was taken from each faculty according to students' number and their sex in each faculty.

Tools

Self-administered questionnaire, it was structured to include four parts

Part (1) Personal data included: Student' age, sex, religion, faculty name, class, governorate, and residence, resident during study, marital statues, level of education and occupation of parents.

Part (2): It consisted of students' knowledge regarding organ transplantation and organ donation included 19 questions distributed as following ( source of knowledge, time of organ donation, people who can donate their organs, diseases that need organ transplantation in Egypt, organs that can be donated, risks in organ donation process, laws which govern the process of organ transplants, religion opinion about organ donation and transplantation and importance of organ transplants process, ...etc).

The students' knowledge was measured by scoring system, score one grade for correct answer and zero grade for incorrect answer. Total scoring for measure knowledge was (52) grade. The score of each item was summed-up and then converted into a percent 
score $($ poor $=$ score $<50 \%$, average $=$ score $50-70 \%$, good $=$ score $>70 \%$ (Khalaf, 2012).

Part (3): It consisted opinions about organ donation and transplantation included (14) statements distributed as following: (organ donation leads to the spread of organ trade, organ donation lead to the spread of killing persons and stealing their organs, organ donation should be to a person belonging to same religion, organ donation should be to a person belonging to same nationality, people are free to donate their organs and people are free to sell their organs,...etc). And students' willingness to donate their organs and their reasons.

- The students' opinions were measured by scoring system, score one grade for agreement and zero grade for disagreement. Total scoring for measures the opinions was (12) grades. Total score was calculated by summing-up and then converting into a percent score. Students' opinions was considered positive if the score was $>60 \%$ and negative opinions if the score was $<60 \%$ ) (Khalaf, 2012).

\section{Validity of tools content}

Self-administered questionnaire was developed by a researcher on the basis of the relevant literature and reviewed by 2 experts in public health medicine and 3 experts in community health nursing.

\section{Methods}

Before conducting the study, an official approval letter was obtained from the dean of faculty of Nursing, Assiut University, to the deans of each selected faculties, the letter included a permission to carry out the study and explained the purpose and nature of the study. The researcher introduced herself to the deans of each selected faculties and give them a copy of the official approval letter, The researcher reminded them of the nature and purpose of the study and she asked them to take a copy of the study schedules of the selected grades of faculties involved in this study. Also, the researcher took oral permission from the teaching staff members who were responsible for the desired lectures or sections, depending on their persuasion, thinking and the nature of each faculty

\section{Field of the work}

Data was collected in the period from the first of February 2013, until the end of April 2013. The researcher collected the sample through three days every week (one faculty per week), she went to each faculty and introduced her self to the lecturers whose assisted her to collect the data, then introduced herself to the students and explained the purpose and nature of the study to them. Then she obtained an oral informed consent from each student to participate in the study.

\section{Pilot study}

Pilot study was carried out before starting data collection on (45) students, which was excluded from the sample. The aim of pilot study was to test the clarity of the tool and to estimate the time required to fill the questionnaire. Based on the results of this pilot study modifications in the tools were done.

\section{Quality control}

The standardization of the interviewer was done with continuous supervision and quality control $5 \%$. Supervisor visited the researcher during the data collection phase and asked the students about their understanding of the questionnaire, the time they need to fill out the questionnaire, and the difficulties they face.

\section{Ethical consideration}

The researcher explained the purpose and nature of the study for each student. The student has the right to agree or disagree on participation in the study; consent to participate in the study was secured orally from every student and informed that the information obtained will be confidential and used only for the purpose of the study.

\section{Statistical analysis and scoring system}

The obtained data was reviewed, prepared for computer entry, coded, analyzed and tabulated. Descriptive statistics (frequencies, percentage, mean and standard deviation) were done using computer program SPSS version 16. Chi-square and Pearson correlation tests were used to investigate the presence of a statistical significance with ranked variables. Statistical significance was considered at p-value were less than $0.05(\mathrm{p}<0.05)$. 


\section{Results}

Table (1): Percentage distribution of studied students regarding to their personal characteristics at Assuit University, $($ No $=1075)$.

\begin{tabular}{|c|c|c|}
\hline Personal characteristics & No. (1075) & $\%$ \\
\hline \multicolumn{3}{|l|}{ Age/years } \\
\hline$<20$ years & 501 & 46.6 \\
\hline$\geq 20$ years & 574 & 53.4 \\
\hline Mean \pm SD (Range) & \multicolumn{2}{|c|}{$20.02 \pm 1.45(17-26)$} \\
\hline \multicolumn{3}{|l|}{ Sex } \\
\hline Male & 384 & 35.7 \\
\hline Female & 691 & 64.3 \\
\hline \multicolumn{3}{|l|}{ Religion } \\
\hline Moslem & 939 & 87.3 \\
\hline Christian & 136 & 12.7 \\
\hline \multicolumn{3}{|l|}{ Residence } \\
\hline Rural & 660 & 61.4 \\
\hline Urban & 415 & 38.6 \\
\hline \multicolumn{3}{|l|}{ Students' resident during study } \\
\hline University dormitories & 557 & 51.8 \\
\hline Family home & 400 & 37.2 \\
\hline Outside campus & 118 & 11.0 \\
\hline \multicolumn{3}{|l|}{ Marital status } \\
\hline Single & 1061 & 98.7 \\
\hline Married & 14 & 1.3 \\
\hline \multicolumn{3}{|l|}{ Father education } \\
\hline Illiterate & 74 & 6.9 \\
\hline Read \& write & 110 & 10.2 \\
\hline Basic education & 151 & 14.1 \\
\hline Secondary education & 276 & 25.6 \\
\hline University & 464 & 34.2 \\
\hline \multicolumn{3}{|l|}{ Mother education } \\
\hline Illiterate & 206 & 19.2 \\
\hline Read \& write & 152 & 14.1 \\
\hline Basic education & 180 & 16.7 \\
\hline Secondary education & 232 & 21.6 \\
\hline University & 305 & 28.4 \\
\hline \multicolumn{3}{|l|}{ Father occupation } \\
\hline Professional & 316 & 29.4 \\
\hline Farmer & 110 & 10.2 \\
\hline Employee & 305 & 28.4 \\
\hline Others (Free job, Retired and Dead) & 344 & 32.0 \\
\hline \multicolumn{3}{|l|}{ Mother occupation } \\
\hline Housewives & 679 & 63.2 \\
\hline Working & 396 & 36.8 \\
\hline
\end{tabular}


Table (2): Percentage distribution of studied students regarding to their knowledge about organ transplantation process at Assuit University, $($ No $=1075)$.

\begin{tabular}{|c|c|c|}
\hline Items & No.( 1075) & $\%$ \\
\hline \multicolumn{3}{|c|}{ Know organ transplantation and donation } \\
\hline Know & 1027 & 95.5 \\
\hline Don’t Know & 48 & 4.5 \\
\hline \multicolumn{3}{|l|}{ Know the concept of brain death } \\
\hline Know & 886 & 82.4 \\
\hline Don’t Know & 189 & 17.6 \\
\hline \multicolumn{3}{|c|}{ Possibility of recovering person from brain death } \\
\hline Yes & 700 & 65.1 \\
\hline No & 375 & 34.9 \\
\hline \multicolumn{3}{|l|}{ Time of organ donation: ${ }^{(*)}$} \\
\hline During the life & 674 & 62.7 \\
\hline After death & 655 & 60.9 \\
\hline During the alarming brain death & 370 & 34.4 \\
\hline Don't know & 219 & 20.4 \\
\hline \multicolumn{3}{|l|}{ People who can donate organs: ${ }^{(*)}$} \\
\hline Adults & 848 & 78.9 \\
\hline Children & 414 & 38.5 \\
\hline Elderly persons & 495 & 46.0 \\
\hline Do not know & 163 & 15.2 \\
\hline \multicolumn{3}{|c|}{ Diseases that need organ transplants in Egypt: ${ }^{(*)}$} \\
\hline Renal failure & 953 & 88.7 \\
\hline Cancer & 346 & 32.2 \\
\hline Cancer liver & 637 & 59.3 \\
\hline Blood diseases & 389 & 36.2 \\
\hline Heart disease & 521 & 48.5 \\
\hline Blindness & 482 & 44.8 \\
\hline \multicolumn{3}{|c|}{ Knowledge about the importance of organ transplants Process } \\
\hline Know & 444 & 41.3 \\
\hline Don't Know & 631 & 58.7 \\
\hline
\end{tabular}

${ }^{(*)}$ More than one answer was selected

Table (3): Percentage distribution of studied students regarding to their Sources of Information about organ transplantation and donation at Assuit University, $($ No $=1075)$.

\begin{tabular}{|l|c|c|}
\hline \multicolumn{1}{|c|}{ Items } & No. (1027) & \multicolumn{2}{c|}{} \\
\hline Sources of information $^{(*)}$ & 1024 & 7.99 \\
\hline Mass media & 369 & 35.9 \\
\hline Internet & 439 & 42.7 \\
\hline Study through curriculum & 319 & 31.1 \\
\hline Colleagues & 348 & 33.9 \\
\hline Health teams & 580 & 56.5 \\
\hline Books and newspapers & 6 & 0.6 \\
\hline Others( Family members, Friends) & & \\
\hline
\end{tabular}

(*) More than one answer were selected 
Table (4): Percentage distribution of studied students regarding to their opinion about organ donation in the Egyptian society at Assuit University, (No = 1075).

\begin{tabular}{|c|c|c|}
\hline Items & No. $(n=1075)$ & $\%$ \\
\hline \multicolumn{3}{|c|}{ Agreement on organ donation in the Egyptian society } \\
\hline Yes & 419 & 39.0 \\
\hline No & 446 & 41.5 \\
\hline I don't know & 210 & 19.5 \\
\hline \multicolumn{3}{|l|}{ Reasons for agreement $(n=419):^{(*)}$} \\
\hline Religious reasons & 74 & 17.7 \\
\hline Health reasons & 109 & 26.0 \\
\hline Humanity reasons & 301 & 71.8 \\
\hline Financial reasons & 12 & 2.9 \\
\hline \multicolumn{3}{|l|}{ Reasons for refusing $(n=446):^{(*)}$} \\
\hline Religious reasons & 183 & 41.0 \\
\hline Health reasons & 161 & 36.1 \\
\hline Humanity reasons & 153 & 34.3 \\
\hline Financial reasons & 28 & 6.3 \\
\hline
\end{tabular}

${ }^{(*)}$ More than one answer were selected

Table (5): Percentage distribution of studied students regarding to their willingness to donate their organs at Assuit University, (No = 1075).

\begin{tabular}{|c|c|c|}
\hline Items & No.( 1075) & $\%$ \\
\hline \multicolumn{3}{|l|}{ Willing to donate your organs: } \\
\hline Yes & 419 & 39.0 \\
\hline No & 438 & 40.7 \\
\hline I don't know & 218 & 20.3 \\
\hline \multicolumn{3}{|c|}{ Reasons for accepting organ donation $(n=419):^{(*)}$} \\
\hline Religious reasons & 99 & 23.6 \\
\hline Health reasons & 55 & 13.1 \\
\hline Humanity reasons & 312 & 74.5 \\
\hline Financial reasons & 2 & 0.5 \\
\hline \multicolumn{3}{|c|}{ Reasons for refusing of organ donation $(n=438):{ }^{(*)}$} \\
\hline Religious reasons & 159 & 36.3 \\
\hline Health reasons & 243 & 55.5 \\
\hline Humanity reasons & 62 & 14.2 \\
\hline Financial reasons & 17 & 3.9 \\
\hline
\end{tabular}

${ }^{(*)}$ More than one answer were selected 
Figure (1) Distribution of studied students regarding level of their knowledge towards organ transplantation and organ donation.

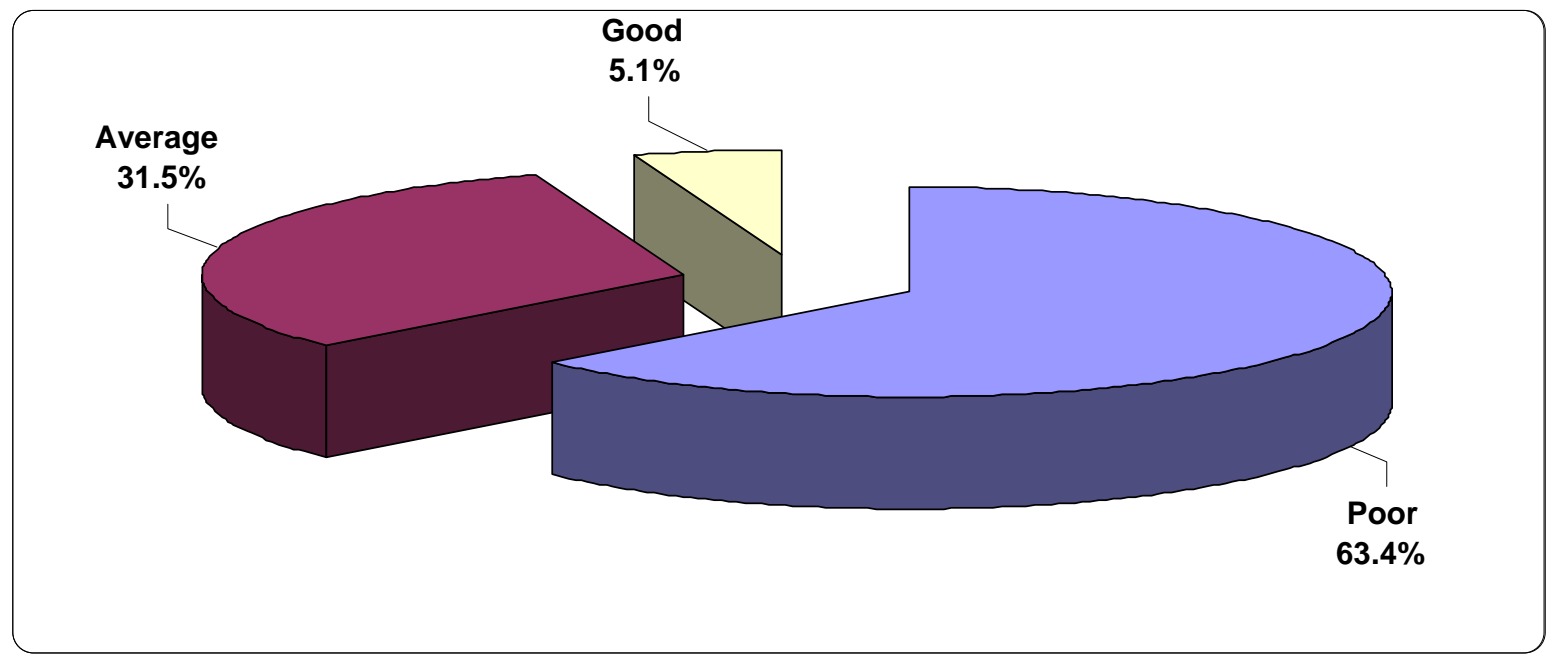

Figure (2) distribution of studied students regarding their opinions towards organ transplantation and organ donation.

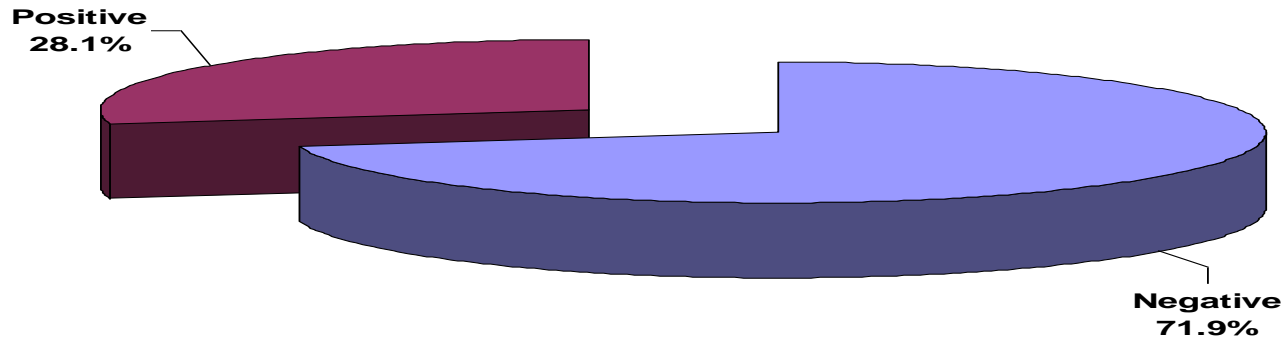

Figure (3) Distribution of students' opinions about organ transplantation and organ donation regarding their sex at Assuit University, 2013.

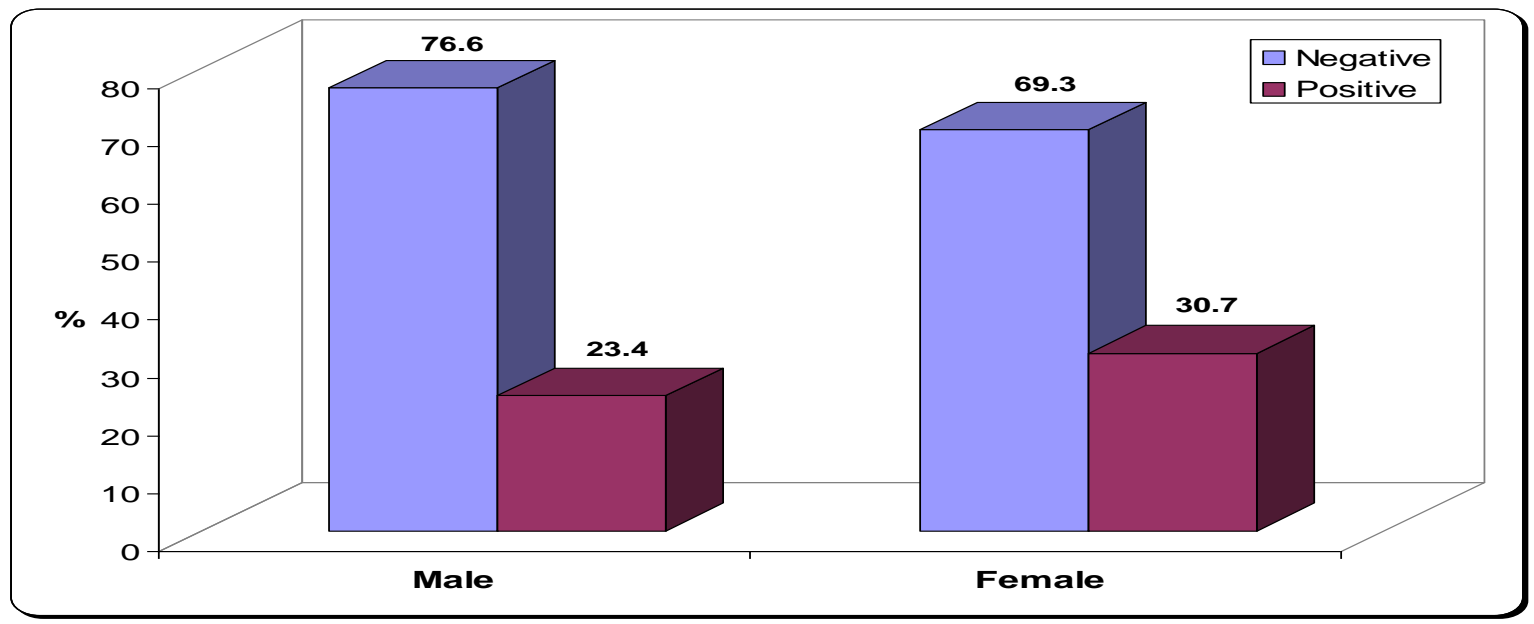


Figure (4) Distribution of students' opinions about organ transplantation and organ donation regarding their type of education at Assuit University, (2013).

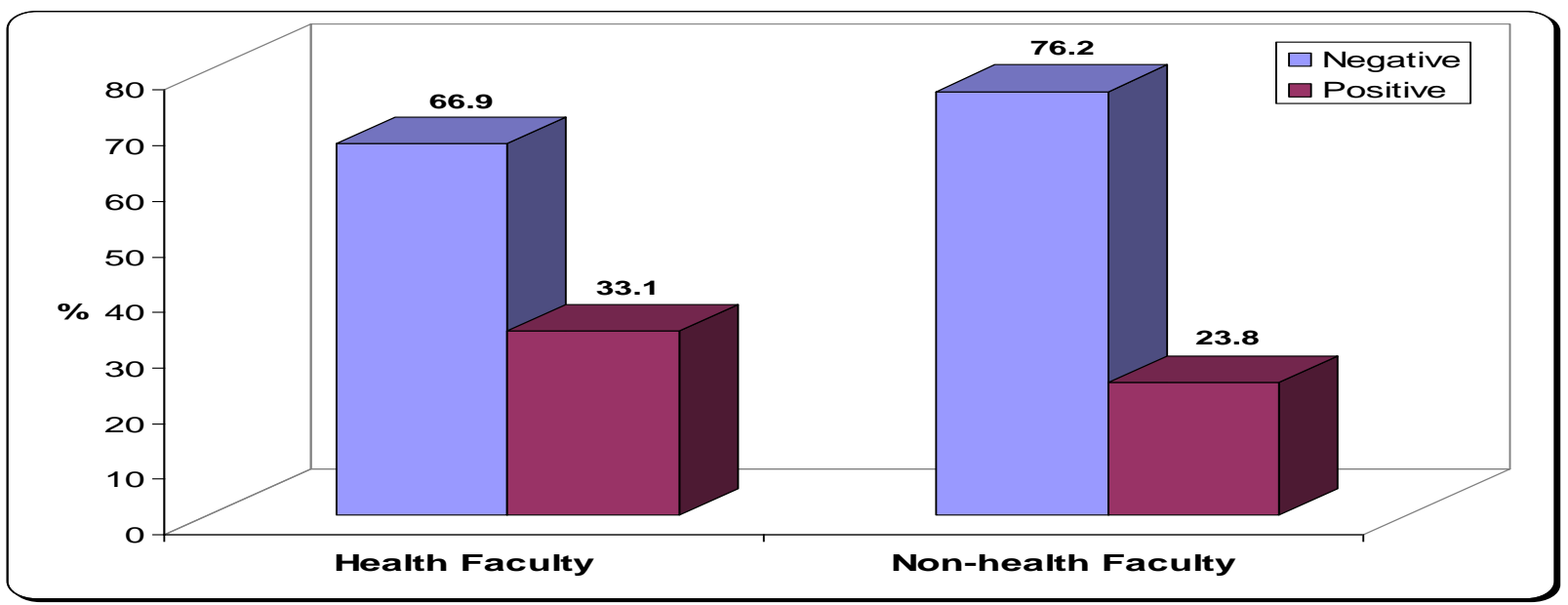

Table (6): Relation between student's knowledge about organ transplantation and donation and their personal characteristics.

\begin{tabular}{|c|c|c|c|c|c|c|c|}
\hline \multirow{3}{*}{ Items } & \multicolumn{6}{|c|}{ Level of knowledge } & \multirow{3}{*}{ P-value } \\
\hline & \multicolumn{2}{|c|}{ Poor $(n=681)$} & \multicolumn{2}{|c|}{ Average $(n=339)$} & \multicolumn{2}{|c|}{ Good $(n=55)$} & \\
\hline & No. & $\%$ & No. & $\%$ & No. & $\%$ & \\
\hline \multicolumn{7}{|l|}{ Age } & \multirow{4}{*}{$0.001 *$} \\
\hline$<20$ years & 339 & 67.7 & 144 & 28.7 & 18 & 3.6 & \\
\hline $20-21$ years & 239 & 62.4 & 126 & 32.9 & 18 & 4.7 & \\
\hline$>21$ years & 103 & 53.9 & 69 & 36.1 & 19 & 9.9 & \\
\hline \multicolumn{7}{|l|}{ Gender } & \multirow{3}{*}{$0.004^{*}$} \\
\hline Male & 263 & 68.5 & 111 & 28.9 & 10 & 2.6 & \\
\hline Female & 418 & 60.5 & 228 & 33.0 & 45 & 6.5 & \\
\hline \multicolumn{7}{|l|}{ Religion } & \multirow{3}{*}{$0.004 *$} \\
\hline Moslem & 588 & 62.6 & 303 & 32.3 & 48 & 5.1 & \\
\hline Christian & 93 & 68.4 & 36 & 26.5 & 7 & 5.1 & \\
\hline \multicolumn{7}{|l|}{ Residence } & \multirow{3}{*}{$0.009 *$} \\
\hline Rural & 440 & 66.7 & 193 & 29.2 & 27 & 4.1 & \\
\hline Urban & 241 & 58.1 & 146 & 35.2 & 28 & 6.7 & \\
\hline \multicolumn{7}{|l|}{ Faculty type } & \multirow{3}{*}{$0.000^{*}$} \\
\hline Health Faculty & 270 & 54.4 & 181 & 36.5 & 45 & 9.1 & \\
\hline Non-health Faculty & 411 & 71.0 & 158 & 27.3 & 10 & 1.7 & \\
\hline \multicolumn{7}{|l|}{ Grades } & \multirow{3}{*}{$0.002 *$} \\
\hline First year & 388 & 66.9 & 173 & 29.8 & 19 & 3.3 & \\
\hline Last year & 293 & 59.2 & 166 & 33.5 & 36 & 7.3 & \\
\hline
\end{tabular}

Chi-square test

*Statistical highly significant difference $P<0.001$ 
Figure (5) Correlation between score of knowledge and opinions of students towards organ transplantation and organ donation at Assuit University, (2013).

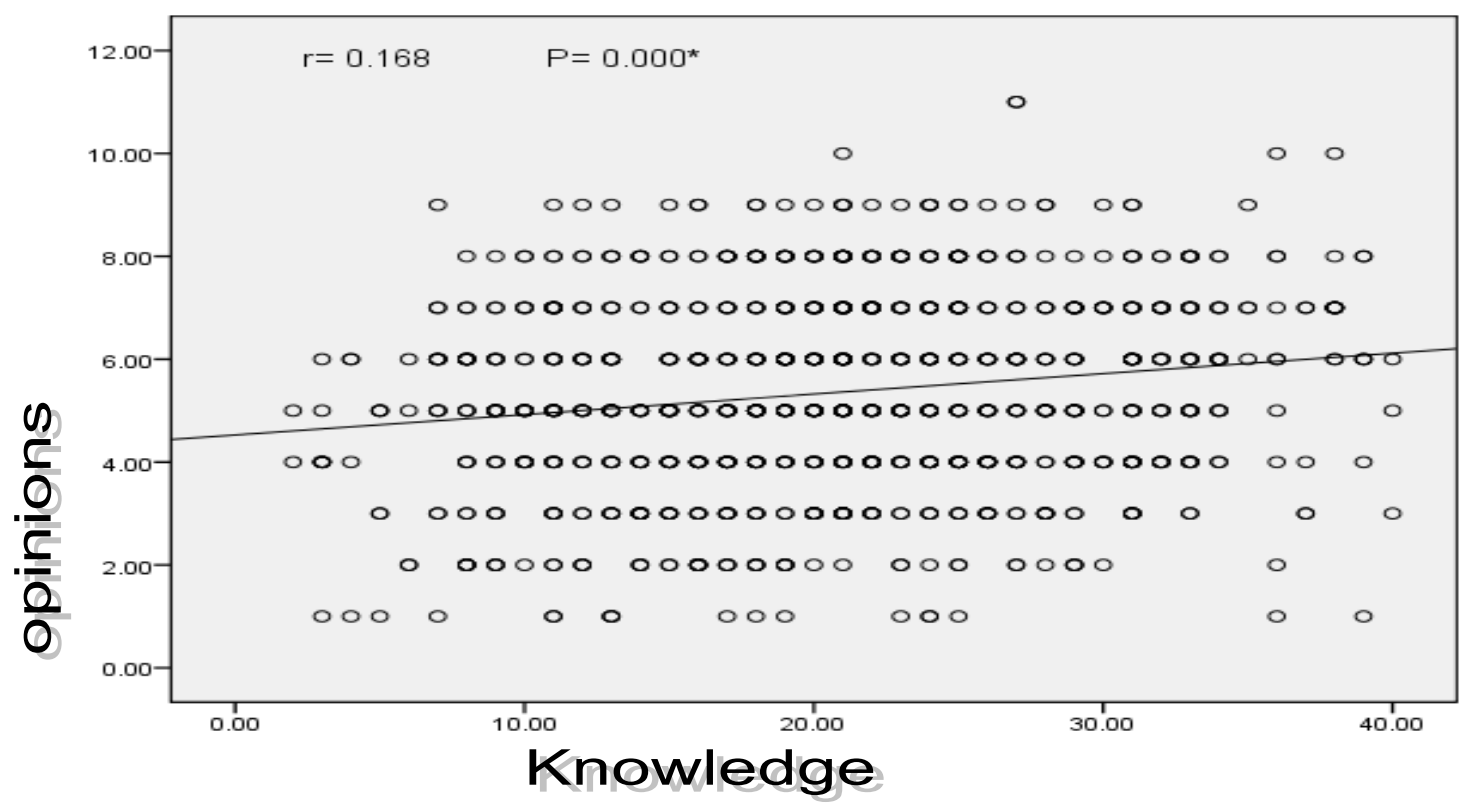

Table (1): Shows distribution of students regarding to their personal characteristics, It was found that less than half $(46.6 \%)$ of the students aged less than 20 years and more than half $(53.4 \%)$ of them their age were more than 20 years old. The mean age \pm SD was $20.02 \pm 1.45$. As regard to gender, less than two thirds $(64.3 \%)$ of students were females. regarding student's religion; the majorities $(87.3 \%)$ of them were Moslems. According to residence, less than two thirds $(61.4 \%)$ of the students live in rural area, while slightly more than half $(51.8 \%)$ of students live in University dorms during the study. Concerning the marital status, the vast majority $(98.7 \%)$ of the students were single. With regards to their parent's education, it was found that $(43.2 \%)$ of students' father had University education, while $28.4 \%$ of students' mothers had University education. According to occupation of their parents, it was estimated that less than one third $(29.4 \%)$ of students' father were professional, while less than two third $(63.2 \%)$ of students' mothers were housewives.

Table (2) : Represent distribution of students regarding to their knowledge about organ transplantation process. Concerning the students' knowledge about organ transplantation process, it was found that vast majority $(95.5 \%)$ of the students knows about it. Also majority (82.4\%) of them knows the brain death concept. As regarding to the possibility of recovering a person from brain death, $34.9 \%$ of the students presented correct answer. According to the time of organ donation, (62.7\%) of the students stated that during the life, and (20.4\%) of them stated they don't know. Also, this table shows that more than three quarter $(78.9 \%)$ of the students stated that adults who can donate their organs. As regarding to the diseases that need organ transplants in Egypt. The majority $(88.7 \%)$ of the students reported that renal failure is the most disease need transplantation in Egypt. More over, 58.7\% of them know the importance of organ transplants process.

Table (3) : Shows distribution of students regarding to their sources of information about organ transplantation and donation. It was revealed that mass media such as television and radio $(99.7 \%)$ was considered the main source of information, followed by books and newspapers $56.5 \%$ and study through curriculum $(42.7 \%)$.

Table (4) : Shows distribution of students regarding to their opinion about organ donation in the Egyptian society and their reasons. It was noticed that more than two fifths $(41.5 \%)$ of the studied sample disagreed on organ donation in Egyptian society. With regard to their reasons for refusing, more than two fifths $(41.0 \%)$ of the students stated religious reasons and only $6.3 \%$ of them stated financial reasons. While more than one third $(39.0 \%)$ of the students agreed on organ donation in the Egyptian society, and in relation to their reasons for agreement more than two thirds $(71.8 \%)$ of students said they were humanitarian reasons and only (2.9) said they were financial reasons. 
Table (5) : Illustrates distribution of students regarding to their willingness to donate their organs, it was found that $(39.0 \%)$ of the studied sample were willing to donate their own organs. With regard to their reasons for accepting organ donation, it was found that slightly less than three quarters (74.5\%) of students reported humanitarian reasons and only $0.5 \%$ of them reported financial reasons. While about two fifths $(40.7 \%)$ of students not willing to donate their own organs, and in relation to their reasons for refusing of organ donation, it was found that more than half $(55.5 \%)$ of students reported health reasons and only $(3.9 \%)$ of them reported financial reasons.

Figure (1):.Illustrates total score of students' knowledge about organ transplantation and organ donation. It was found that less than two thirds $(63.4 \%)$ of studied students had poor knowledge and less than one third $(31.5 \%)$ of them had satisfactory score of knowledge, while only $5.1 \%$ of them had good knowledge.

Figure (2): Shows total score of students' opinions towards organ transplantation and organ donation. It was noticed that less than three quarters $(71.9 \%)$ of studied students had negative opinions towards organ transplantation and organ donation.

Figure (3): Shows distribution of students' opinions about organ transplantation and organ donation regarding their sex, it was found that more than three quarters $(76.6 \%)$ of males had negative opinions, while about one third $(30.7 \%)$ of female had positive opinions.

Figure (4): Represents the distribution of students' opinions about organ transplantation and organ donation regarding their type of education. It was found that about two thirds $(66.9 \%)$ of .the students in health faculties had negative opinions, while less than a quarter $(23.8 \%)$ of students in non health faculties had positive opinions.

Table (6): Represents the relation between students' knowledge about organ transplantation and donation and their personal characteristics. It was revealed that there was a significant statistical relation between students' knowledge and their age $(p=0.001)$; sex $(\mathrm{p}=0.004)$; religion $(\mathrm{p}=0.004)$; residence $(\mathrm{p}=0.009)$; resident during study $(\mathrm{p}=0.022)$; faculty type $(p=0.000)$ and college grades $(p=0.002)$.

Figure (5): Shows correlation between score of knowledge and opinions of students towards organ transplantation and organ donation. It was revealed that there is a positive correlation between score of knowledge and opinions of students towards organ transplantation and organ donation.

\section{Discussion}

In Egypt, more contested than any other bioethics topic, organ transplantation has been taken up in the mass media - in print, state television, radio, film, and religious sermons. Patients, family members, physicians, and others in Egypt differ in opinions about whether organ transplantation actually "saves lives" (Hamdy, 2010). The University students represent the future of the community and have a direct influence on other family members and friends, and their opinions of this matter reverse the opinions of their family, friends, and their communities (Conesa et al., 2004). The current study is trying to determine the level of knowledge and its determinants toward organ donation and transplantation among University students and identify their opinions about organ donation.

In the present study, more than half of the participated students aged 20 years or more and the mean age of them were $(20.02 \pm 1.45)$. Similar finding were reported by (Doğan et al., 2012) who conducted a study to investigate students' knowledge, attitude and behaviors of university students on organ donation in Turkey and reported the same age which range from $(17-26)$ years or more with the mean of students' age were $20.3 \pm 1.8$ years.

The present study also showed that there was statistical significant relation between student's age and their knowledge $(\mathrm{p}=0.001)$. This result was in the same line with (Agbenorku, 2013) who found that, there was statistical significant relation between student's age and their level of awareness $(\mathrm{p}=0.02)$. Moreover, this result disagreed with (Khan et al., 2011) who found that there is no statistical significant difference between people' age and their knowledge $(\mathrm{p}=0.575)$.

According to the student sex, the result of the present study revealed that the majority of the participated students were females; this could be a result of the presence of the college of Nursing within the study sample (All students in the college of Nursing females). Also, those Female students more committed to attend the lectures than male students. There was statistical significant difference between students' knowledge and their sex $(\mathrm{p}=0.004)$. These results agreed with (Piccoli, 2006) who found that females were more likely to answer positively $(\mathrm{P}<0.001)$.

In addition, in this study the majority of students were Muslims. Also, there was statistical significant difference between students' knowledge and their religion $(\mathrm{p}=0.004)$. This result disagreed with (Pham and Spigner, 2004) who found that there was no statistical significant difference between students' knowledge and their religion $(\mathrm{p}=0.351)$. 
Concerning residence of the studied sample, less than two thirds of the students were from rural area, while more than one third of students were from urban area, and there was statistically significant relation between student's knowledge and their residence $(\mathrm{P}=0.009)$. These results agreed with (Alghanim, 2010) who found that the respondents in the rural areas had a significantly lower percentage of knowledge about organ donation and transplantation than the respondents in the urban ones $(\mathrm{P}<0.0001)$.

Also, the present study showed that there was statistically significant relation between student's knowledge and their type of education $(\mathrm{P}=0.000)$. And was found that students in health sector faculties had good knowledge than those in non-health sector faculties. It may be interpreted by that students in health sector faculties studied about organ transplantation and donation in their curriculum. This result is in the same line of (Jawahar, 2006) who found that there was statistical significant difference in knowledge between medical and non-medical students.

In a study conducted by (Ali, 2013) who found that the primary source of the students' knowledge about the term 'Organ Donation' was media (64.6\%) followed by friends/family (50\%), newspaper/magazines and only more than one quarter reported healthcare providers.

Also, this study agree with (Parushetti, 2012) who that $(78.00 \%)$ of participants had heard about organ donation, and their sources of information were TV $48.88 \%$, radio $35 \%$, news paper $(29.45 \%)$, journals $(2.54 \%)$, friends $(14.35 \%)$, internet $(3.44 \%)$. The findings of the present study revealed that, the majority of the students knew about organ transplantation and organ donation and their sources of information were from mass media (television and radio)as stated by the vast majority of students.

In regard to students' knowledge about the concept of brain death, the present study revealed that, the majority of the students indicated that they knows about the brain death concept, while only $17.6 \%$ of them noted that they did not know it. This is because the study sample was containing students from health science faculties such as medicine, nursing, and pharmacy who study about medical issue like the concept of brain death in there curriculum.

This findings agreed with (Terada et al., 2004) who found that the majority of the students claimed to have "knowledge" regarding the criterion for brain death, and (17.4\%) of them claimed to have "no knowledge "regarding them.

Concerning the possibility of recovering person from brain death, the present study revealed that, about two thirds of participants gave incorrect answer, this may be related to poor understanding of the concept of brain death among the students. This result agreed with (Doğan et al., 2012) who found that $57.5 \%$ among all faculty students and $44.4 \%$ of college students gave incorrect answer in relation to the possibility of recovering a person from brain death. This result incongruent with (Milaniak et al., 2012) who found that the majority of participants gave correct answer in relation to the possibility of recovering a person from brain death.

In regard to students' knowledge about the time of organ donation, it was found that less than two thirds of students stated that during the life only, while more than one third of them stated that during brain death period. The reason for this, may be due to the fact that organ donation in Egypt depends on living persons only, i.e. directed donation to a loved one or friend (directed related) and directed donation to a stranger, also Egypt has been one of the few countries that prohibited organ donation from deceased donors. These results agreed with (Iliyasu et al., 2014) who found that $65.9 \%$ of the participants said that organs for donation could come from living donors only.

Regarding students' knowledge about the people who can donate organs, the present study indicated that, more than three-quarters of the students stated that adults, less than half of the students said that elderly people and more than one-third of them said that children can donate organs. It may be explained by that most of the students thought that the process of organ transplantation need to healthy people are able to donate, and this applies to adults more than children and the elderly, also, this may be due to the fact that the students' knowledge about organ donation is taken from the media, which, in most cases, presenting the adult as only persons who can donate organs. These results disagreed with (Alghanim, 2010) who found that (37.1\%) of respondents stated that only organs of young people can be donated.

In the present study, the majority of respondents knew the benefits behind organ donation e.g. (it could save lives of other people) these findings agreed with (Alam, 2007) who found that the majority (91.1\%) of respondents knew that many lives could be saved by organ donation. This result disagreed with (Parushetti, 2012) who found that only $(16.00 \%)$ of participant told that organ donation is done about organ donation and organ transplantation to save the life of recipient.

According to the total knowledge score for students about organ transplantation and organ donation, this study revealed that $(63.4 \%)$ of the students had poor knowledge; this may be related that correct information about the issue wasn't prevalent among them. While less than one third of them were satisfactory and only $(5.1 \%)$ of the students had good 
knowledge. that may be due to many reasons such as, the educational program for university education doesn't contain sufficient information about the issue, insufficient emphasis on organ donation in the medical curriculum, and paucity of organ donation public awareness campaigns in the community as well as religious and legal ambiguities. This finding agreed with (Edwards et al., 2007) who found that many of the students had low knowledge of the donation and transplantation process.

This result disagreed with (Wei et al., 2012) who mentioned that more than $(90.0 \%)$ of the participants possessed a degree of knowledge about organ transplantation. And with (Milaniak et al., 2012) who found that the majority of respondents have a good knowledge about organ donation and transplantation was $(60 \%)$. Also, these results disagreed with (Iliyasu et al., 2014) who found that the level of awareness of organ donation among respondents was $(79.6 \%)$.

As regard to students' opinions about organ donation, the present study revealed that less than three quarters $(71.9 \%)$ of students had negative opinions towards organ donation, while less than one third $(28.1 \%)$ of students had positive opinions. We can explain this finding on the basis of religious and legal ambiguities about organ transplantation and organ donation. Fear of organs being used for the purposes of organ trafficking, lack of proper knowledge, concerns about body manipulation, and finally the effect of printed and visual press which does not provide adequate information on organ donation, and most of this news about organ transplantation is about excessively tragic transfer and about tragic death confronted by cadaver donors rather than importance of the transplantation procedure and, thus, views about organ transplantation may be negatively influenced.

This study disagreed with (Doğan et al., 2012) a large part of students reported positive views on organ donation. Moreover this was contradicted with (Milaniak et al., 2012) who found that $88.29 \%$ of responders expressed positive attitudes towards organ donation.

In addition, the present study revealed that there was a statistically significant relation between students' opinions and their age $(\mathrm{p}=0.046 \%)$, sex $(\mathrm{p}=0.011 \%)$, religion $(\mathrm{p}=0.028 \%)$ and faculty type $(\mathrm{p}=0.001 \%)$. These results in the same line with (Agbenorku, 2013) who found that statistical significant for attitude toward organ donation was identified among younger age $(p=0.04)$. Also this result agreed with (Sanavi, 2012) who found that the attitude and willingness of students had a positive correlation with their age $(\mathrm{P}=0.027$ and $\mathrm{P}=0.031$, respectively).

On otherwise, this result disagreed with (Al-Ghanim, 2008) who found that respondents from the non- medical colleges were more willing to donate organs than students from medical colleges $(\mathrm{p}=0.005)$.

According to students' opinions about organ donation in the Egyptian society, the present study revealed that more than one third $(39.0 \%)$ of the students agreed on organ donation in the Egyptian society, while less than half of students disagreed on organ donation in the Egyptian society. Their main reasons for refusing were religious reasons, followed by health reasons, humanitarian reasons, and financial reasons.

Regarding students' willingness to donate organs and their reasons, $(39.0 \%)$ of students were willing to donate their organs, the main reasons for donating were humanity reasons, followed by religious reasons, health reasons and financial reasons. While about two fifths $(40.7 \%)$ of students were not willing to donate their organs, the main reasons for not donating were health reasons, followed by religious reasons, Humanity reasons and financial reasons.

This result in the same line with (Jawahar, 2006) who found that $(32.5 \%)$ of students were willing to donate an organ. Fear of misuse of organ (29.9\%) and fear of being cut open/mutilated (29\%). are the major reasons preventing the people from donating organs. On other hand, these findings disagreed with (Iliyasu et al., 2014) who found that $(79.1 \%)$ respondents were willing to donate, the reasons included religious issues (51.2\%), moral obligation (21.4\%), compassion/sympathy (11.9\%), and anticipated reciprocity $(9.4 \%)$ and just to save life $(6.1 \%)$. On the other hand, unwilling respondents also cited religious reasons $(7.8 \%)$, lack of incentives $(24.7 \%)$ and fear of dying in the process $(37.7 \%)$. Also, this result disagreed with (Doğan et al., 2012) who found that $(81.2 \%)$ of students were willing to donate organs; primary reasons reported by students with negative view on organ donation were presence of religious barriers and discouragement.

The current study showed that there was a positive correlation between score of knowledge and opinions towards organ transplantation and organ donation. This result in the same line with (Milaniak et al., 2012) who found that a high level of knowledge and high level of altruism were positively related to willingness to be an organ donor and bone marrow donor $(\mathrm{p}<.08)$. Also, this result agreed with (Saleem et al., 2009) who found that knowledge score for organ donation was found to be associated with motivation to donate.

These results disagreed with (Mekahli et al., 2009) who found that the logical regression test was not able to identify any influence of knowledge on students' willingness to donate. Also, this result disagreed with (Bilgel et al., 2006) who found that the students' knowledge about organ donation and 
organ transplantation were not significantly associated with willingness to donate.

\section{Conclusion}

The present study provides an understanding of the knowledge and opinions about organ transplantation and organ donation among Assiut University students. It was found that less than two thirds of Assiut University students had poor knowledge about organ transplantation and organ donation, while the majority of them had negative opinion about it. Also The present study found that there was a positive correlation between total score of students' knowledge and total score of students' opinions towards organ transplantation and organ donation. Therefore, more dissemination of information can increase the awareness of the public, including students to the importance of organ donation and transplantation.

\section{Recommendations}

Based on the result of the present study the researcher recommended that improve student's awareness and knowledge about organ donation and transplantation by urging those setting the curriculums to add this subject in the curriculum and that could address some of the deficiencies in students' information about this topic especially in relevant faculties, such as faculties of medicine, nursing, pharmacy and law, also conducting ongoing scientific seminars for students and provide brochures on this subject in the university library. Also, we suggests that institutions such as schools, universities, and health facilities, together with religious leaders, and the media should work together to increase awareness on organ donation. By providing extensive educational programs for students about organ donation and transplantation and provide them with relevant information, including the benefits of organ donation and potential risks so students can make informed decisions in the future.

\section{Reference}

1. Agbenorku P., Agbenorku M., and Agamah G., (2013): Awareness and attitudes towards face and organ transplant among the people of Kumasi, Ghana, Ghana medical journal, Vol. 47, NO. 1 ; Pp30-35

2. Alam A., (2007): Public opinion on organ donation in Saudi Arabia, Saudi center for organ transplantation, Saudi J Kidney Dis Transplant 18(1):Pp54-59.

3. Al Ghanim S., (2008): The willingness toward deceased organ donation among university students, Saudi Med J 2009; Vol. 30 No. (10): Pp1340-1345.

4. Alghanim S., (2010): Knowledge and attitudes toward organ donation: A community-based study comparing rural and urban populations, health and hospital administration program, College of business administration, King Saud University, Riyadh, Saudi Arabia, Saudi J Kidney Dis Transpl;21(1):Pp23-30.

5. Ali N., Qureshi A., Jilani B., and Zehra N., (2013): Knowledge and ethical perception regarding organ donation among medical students, BMC Medical Ethics, 14:38, Pp2-7.

6. Bilgel H., Sadikoglu G., and Bilge N., (2006): Knowledge and attitudes about organ donation among medical students, Turkey, Transplantationsmedizin, Vol. 18 No. 94: Pp9196.

7. Budiani-Saberi, D., and Mustafa A., (2010): Care for commercial living donors: the experience of an NGO's outreach in Egypt. Transplant International, European society for organ transplantation; 24(4): Pp317-323.

8. Cebeci F., Sucu G., and Karazeybek E., (2011): The roles of nurses to augment organ donation and transplantation: A survey of nursing students. Transplantation Proceedings, 43, Pp412- 414.

9. Conesa C., Zambudio A., Ramırez P., Canteras M., Rodriguez M., and Parrilla P., (2004): Socio-personal profile of teenagers opposed to organ donation, Nephrol Dial Transplant, Vol. 19 No. 5, Pp1269-1275.

10. Doğan P., Toprak D., Sunal N., Doğan I., (2012): Knowledge, attitude and behaviors of university students on organ transplantation, in Turkey, Smyrna Tip Dergisi; Pp17-25.

11. Edwards T., Essman C., and Thornton G., (2007): Assessing Racial and ethnic differences in medical student knowledge, attitudes and behaviors regarding organ donation, Cleveland, Ohio. Journal of the national medical association, VOL. 99, NO. (2), Pp131-137.

12. El-Elemi A., and El-Gazzaz G., (2010): Moving towards implementation of a clinical ethics consultation program in Egyptian liver transplant units, transplant research and risk management: Suez Canal University, Ismailia, Egypt; 2:Pp41-46.

13. Jawahar S., (2006): Knowledge, attitude and practices of organ donation among college students in Chennai, Stanley Medical College \& Hospital, Chennai; pp2-4.

14. Hamdy S., (2010): The Organ transplant debate in Egypt: a social anthropological analysis, Droit et Cultures numero 59, of Faith and 
Muslim Women) Feminist Collections Vol. 22, No. 3-4: Pp 357-365.

15. Iliyasu Z., Abubakar I., Lawan U., Abubakar M., and Adamu B., (2014): Predictors of public attitude toward living organ donation in Kano, Northern Nigeria, Saudi center for organ transplantation, Saudi J Kidney Dis Transpl; 25(1):Pp196-205.

16. Khalaf F., (2012); knowledge and attitude of Assiut university Dorms students about consanguinity marriage., Thesis Submitted for partial fulfillment of the requirement for Master Degree in Community Health Nursing, Faculty of Nursing, Assiut University, Pp 58-59.

17. Khan N., Masood Z., and Tufail N., et al, (2011): knowledge and attitude of people toward organ donation, Judo, Vol. 2, No. 2:16-20.

18. Mekahli D., Liutkus A., Fargue S., Ranchin B., and Cochat P., (2009): Survey of first-year medical students to assess their knowledge and attitudes toward organ transplantation and donation. Transplant Proc, 41(2):Pp634-638.

19. Milaniak I., Przybylowski P., Ruzyczka E., Wierzbicki K., and Sadowski J., (2012): The opinions of young people on paid organ donation; Organs Tissues \& Cells. 15, Pp 1-32.

20. Parushetti V., (2012): Perceptions of organ donation among people of Kakati Village, in the state of Karnataka, India; dissertation Submitted for partial fulfillment of the requirement for Master Degree in Public Health, Department of Public Health, Jawahalal Neehru College, KLE University. Belgaum, India: Pp58-61.

21. Pham H., and Spigner C., (2004): Knowledge and opinions about organ donation and transplantation among Vietnamese Americans in Seattle, Washington: a Pilot Study. Clin Transplant; 18: Pp707-715.

22. Piccoli G., Soragna G., Putaggio S., and Mezza E., (2006): Efficacy of an educational programme for secondary school students on opinions on renal transplantation and organ donation: a randomized controlled trial, Internal Medicine Department, University of Turin, Italy, Nephrol Dial Transplant; 21: Pp499-509.

23. Rodrigue J., Cornell D., and Howard R., (2009): Relationship of exposure to organ donation information to attitudes, beliefs, and donation decisions of next of kin. Prog Transplant; 19: Pp173.

24. Saleem T., Ishaque S., Habib N., Hussain S., Jawed A., Khan A., and Ahmad M., (2009): Knowledge, attitudes and practices survey on organ donation among a selected adult population of Pakistan, BioMed Central, BMC Medical Ethics; Pp1-12.
25. Sanavi S., Afshar R., and Sanavi N., (2012): Attitude towards tissue donation in Iranian High School Students, Int J Org Transplant Med; Vol. 2 No.(4); Pp 85.

26. Terada I., Otani A., Hiramatsu K., Matsuo M., and Ito H., (2004): Knowledge of Criteria for Brain Death and Attitudes towards Organ Donation and Transplantation of Nursing Professionals in Tottori Prefecture, Japan, Yonago Acta medica;47:Pp53-62.

27. Wei W., Hui T., Hang Y., Hang L., and Xiaodong $Z$, (2012): Attitudes toward organ donation in China, Chin Med J; 125(1):Pp56-62.

28. World Health Organization, (2008): Organ donation and transplantation: Activities, laws and organization. 2008 Report of the Global Observatory on Donation and Transplantation. . http://www.transplant-observatory.org/

29. World Health Organization (2010): Global observation of organ donation and transplantation: Activities, laws and organization, Pp2-4.

30. World Health Organization (2011): The Madrid Resolution on Organ Donation and Transplantation. The Official Journal of the Transplantation Society; Transplantation. Volume 91, Number 11S, Pp S29-S31. www.transplantjournal.com.

31. Zambudio A., Martinez-Alarcon L., and Parrilla P., et al., (2009): Attitude of nursing staff toward organ donation in a Spanish hospital with a solid organ transplant program. Progress in Transplantation; Vol. 19, No. (4): Pp371-377. 